2014-10-07

\title{
Post-World War II Jazz in Britain: Venues and Values 19451970
}

Williams, Katherine

http://hdl.handle.net/10026.1/4429

10.1558/jazz.v7i1.113

Jazz Research Journal

Equinox Publishing

All content in PEARL is protected by copyright law. Author manuscripts are made available in accordance with publisher policies. Please cite only the published version using the details provided on the item record or document. In the absence of an open licence (e.g. Creative Commons), permissions for further reuse of content should be sought from the publisher or author. 


\title{
Post-World War II Jazz in Britain:
}

\section{Venues and Values 1945-1970}

Katherine Williams

Department of Music, Plymouth University

katherine.williams@plymouth.ac.uk

\begin{abstract}
This article explores the ways in which jazz was presented and mediated through venue in post-World War II London. During this period, jazz was presented in a variety of ways in different venues, on four of which I focus: New Orleans-style jazz commonly performed for the same audiences in Rhythm Clubs and in concert halls (as shown by George Webb's Dixielanders at the Red Barn public house and the King's Hall); clubs hosting different styles of jazz on different nights of the week that brought in different audiences (such as the 100 Club on Oxford Street); clubs with a fixed stylistic ideology that changed venue, taking a regular fan base and musicians to different locations (such as Ronnie Scott's Jazz Club); and jazz in theatres (such as the Little Theatre Club and Mike Westbrook's compositions for performance in the Mermaid Theatre).
\end{abstract}

Keywords: jazz; jazz clubs; mediation; reception; venue

\section{Introduction}

The relationship between jazz and its performance spaces is bound up with cultural connotations and audience expectations. From its birth in turn-ofthe-century New Orleans, jazz and its reception have been restricted, legitimized and liberated by different performance venues. In this article, I focus on London in the quarter-century after World War II, showing how different types of venue and the ethos associated with each of them allowed for differing styles of presentation, mediation and reception of jazz.

My relatively narrow geographical and temporal focus allows me to draw specific conclusions that can be applied to the larger jazz scene in Britain. In this twenty-five-year period, jazz was simultaneously presented in a wide variety of ways in London. I shall focus on four: New Orleans-style jazz was commonly performed in Rhythm Clubs (jazz appreciation societies that began life as record circles) and concert halls; jazz clubs such as 
the 100 Club that had a fixed venue, but hosted different styles of jazz on different nights of the week, bringing in different audiences; bebop clubs such as Club Eleven, which existed from 1948 to 1950, and Ronnie Scott's Jazz Club (founded in 1959) changed venue throughout their lifetimes, but hosted visiting and local musicians, providing an idiomatic consistency that ensured a regular and loyal fan base; and the experimental theatres of the 1960s and 1970s that hosted the British free jazz movement. Using these four case studies and methods of jazz appreciation as examples of the post-World War II jazz scene in London, I evaluate who was playing what, in what venue, and to whom, in order to assess the mediation of British jazz through venue, during the period 1945 to 1970.

My sources for this article are drawn from the existing literature on jazz clubs, historical accounts by fans and musicians, contemporaneous periodicals, and interviews I undertook with musicians from the period. ${ }^{1}$ My methodology is therefore a combination of historical and archival research and of ethnographic practices. I use the term 'jazz venue' to refer to any place in which jazz was performed, rather than venues built especially for jazz performance, which has become the common usage of the term.

\section{Early Jazz Venues}

Jazz is commonly understood to have originated and been first performed at the turn of the twentieth century in the Louisiana port city of New Orleans. Although the geographical specificity of the emergence of the music has since been disputed, the colourful narratives surrounding the location and connotations of early jazz performances provide a context and springboard for this discussion of post-World War II jazz venues in Britain. ${ }^{2}$

1. Material in this article is drawn from my interview with trombonist Eddie Harvey (2010). My PhD thesis draws extensively on transcripts from interviews I undertook with other British jazz musicians, including: Bill Ashton, John C. Williams, Dave O'Higgins, Alan Barnes, and Pete Long. It is available at: http://etheses.nottingham.ac.uk/2622/1/ PhD may 2012.pdf (accessed 29 April 2014).

2. Jeff Taylor, for example, states that 'a variety of syncopated styles and repertories, ones related to but distinct from the ragtime and "country blues" traditions, are now known to have evolved in other regions of the country during jazz's formative years. In New York, Chicago, the Southwest, and even the West Coast, African-American popular music traditions both maintained a regional flavor and incorporated elements of the New Orleans style as it was disseminated in the first two decades of the twentieth century' (2000: 41). Interpretations of the early history of jazz can also be found in Burnim and Maultsby (2006).

(c) Equinox Publishing Ltd 2014.

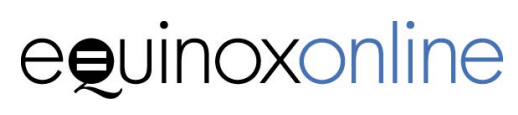


The earliest performances of jazz, in the nightclubs, speakeasies and brothels of New Orleans and elsewhere, were characterized by the improvisatory and energetic 'hot' style of music, and by the intimate dances developed by audiences. The changing nature of jazz venues and reception in the USA over the ensuing decades has been explored in print: Vincent Pelote's 'Jazz Clubs' (2000), Robert P. Crease's 'Jazz and Dance' (2000) and Paul Berliner's 'Vibes and Venues: Interacting with Different Audiences in Different Settings' (1994) are just a few examples. There is very little scholarship on British jazz venues, but a review of the existing literature follows.

\section{Early Jazz Venues: the UK Case}

The history of jazz performance and its mediation through venue in Britain is less documented than its US counterpart, but is equally compelling. The primary texts surrounding jazz in Britain and its associated cultural tropes (performance, reception, education) are Catherine Tackley (née Parsonage)'s 2005 monograph The Evolution of Jazz in Britain, 18801935, George McKay's Circular Breathing: The Cultural Politics of Jazz in Britain from the same year, Duncan Heining's Trad Dads, Dirty Boppers and Free Fusioneers: British Jazz, 1960-1975 (2012), and Hilary Moore's Inside British Jazz: Crossing Borders of Race, Nation and Class (2007). Ian Carr's Music Outside: Contemporary Jazz in Britain (published 1973, with a second edition in 2008) provides a fascinating insider perspective of British jazz at the time. Each of these volumes makes a substantial contribution to the literature concerning British jazz. Parsonage's text offers a comprehensive survey of the first decades of jazz in Britain and associated phenomena, but her temporal focus ends in 1935. Her discussion of the precedents to American jazz musicians visiting London, in the form of indigenous British dance music, Victorian music hall, and musical comedies such as In Dahomey, emphasizes the significance of existing music venues to jazz in Britain. McKay focuses on the political associations of jazz musicians and fans from 1940 to 1970, including jazz accompaniment to protests at Aldermaston and jazz festivals such as Beaulieu, while Heining provides a more documentary and anecdotal report of the later years of that period, illustrating the different jazz venues utilized by trad and modern jazz musicians, and alluding to the importance of the Little Theatre Club and Ronnie Scott's 'Old Place' in the development of British free jazz. Moore uses one case study to illustrate each theme of her title, 'progressing in chronological order and spanning most of the 
last century' (2007: 2). Her narrative strategy enables her to provide an overview of British jazz history and its context, but in focusing on such specific case studies, venue is only discussed in relation to trad band performance. She explains that amateur trad bands all over Britain in the late 1940s 'play[ed] to packed-out halls', and discusses British social dissatisfaction post-World War II, by contextualizing Barnehurst, the location of Rhythm Club No. 130, as a 'physical and metaphorical embodiment of the social climate among the nation's lower classes after the Second World War' (ibid.: 40, 47). (Rhythm Club No. 130 is discussed later in this article.) Carr's account is valuable for its frank assessment of the economic plight facing British jazz musicians in the 1960s and 1970s, and is particularly relevant to my discussion here for his comments on the Little Theatre Club, the Old Place, and the Mermaid Theatre. This article proposes to fill a gap in the existing literature, by focusing on British jazz from 1945 to 1970, as mediated through venue.

The first live jazz performances by American musicians in the UK took place in 1919. The all-white Original Dixieland Jazz Band (ODJB) and the all-black Southern Syncopated Orchestra (SSO) presented different styles of jazz in venues with differing cultural connotations to audiences with differing expectations. The ground had been paved for the first touring jazz musicians in London by the prevalence and popularity of minstrelsy, plantation revues and music-hall performances in Victorian Britain. ${ }^{3} \mathrm{~A}$ model for this normalization of jazz and blues by placing it within an existing context can be seen in the early 'classic' female blues singers of the United States. Bessie Smith, Mamie Smith and Ma Rainey, for example, began their musical lives touring as part of established minstrel troupes, singing within the framework of existing shows (Schuller 1968: 228). ${ }^{4}$

The existing venues in which these early British jazz performances took place carried their own cultural connotations and audience expectations (such as London's Hippodrome, Palladium, and Philharmonic Hall). The Hippodrome had been founded in 1900 as a venue for circus acts, variety theatre and revues, while the London Palladium opened in late 1910 with a 'grand variety theatre act', featuring acts as diverse as music-hall star Nellie Wallace and the classical actor Martin Harvey. The Philharmonic Hall on Great Portland Street had classical-music connotations at the time, but no longer exists as a music site.

3. Parsonage offers an extensive and detailed account of the significance of the early visits of the ODJB and the SSO in The Evolution of Jazz in Britain, pp. 121-62.

4. Michael Pickering (2008) explains the standard format of minstrel shows.

(c) Equinox Publishing Ltd 2014.

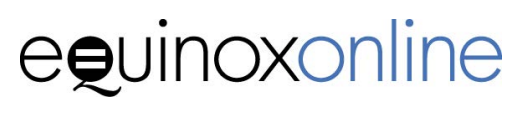


The five-piece ODJB — which comprised cornettist Nick LaRocca, trombonist Eddie Edwards, pianist Henry Raga, clarinettist Larry Shields and drummer Tony Sbarbaro-began their London season in April 1919 as part of the 'Joy Bells' review at the London Hippodrome on Leicester Square. The ODJB's novelty performances ensured that the group fitted well within the existing music-hall and variety-show formats documented by Parsonage (2005: 4). After one performance at the Hippodrome, which according to contemporary spectator $\mathrm{H}$. O. Brunn was met with 'shouting and clapping in a manner peculiarly un-British' (1961: 126), the band began a fortnight's engagement at the London Palladium, as one act of a variety show. The band was accompanied on stage by a dancer, so that jazz was associated with dance from its very earliest British performances, even when these took place in front of a non-dancing audience. The association with dance continued after the ODJB's employment at the Palladium ended, when the band began a long-term engagement at the Dixie Club on Bond Street. The Dixie Club permitted its audience members the space and freedom to dance. In the early ODJB performances, a connection can be made between jazz and venue. By performing first in a venue associated with variety shows, and then moving to a venue that had the physical characteristics to contain a dancing audience, the ODJB's reception in the UK rested upon the venues in which they were heard.

In contrast to the novelty performances of the ODJB in venues associated with music hall and dancing, the SSO (under the direction of Will Marion Cook) first performed in London's Philharmonic Hall in June 1919. The group consisted of up to one hundred musicians, and incorporated strings and orchestral percussion as well as typical jazz instruments. They did not perform jazz exclusively, and frequently incorporated ragtime and light classical repertoire into their programmes. Reviewers and audiences did not initially understand the presentation of many styles of music, and the audience numbers were small (Parsonage 2005: 146). Reviews were generally positive, but even in London (which can be understood to be the most adventurous city in Britain) black music remained recognized on a small scale. Numerous factors contributed to the SSO's reception as an extension of the conventions of classical venues such as the Philharmonic Hall: its chosen repertoire; its billing as an 'orchestra', and its 'presentat[ion] of the music in the format of a traditional concert' (ibid.: 147). From the earliest appearances of jazz in London, it is possible to see that the styles of jazz performed and the connotations of the venues in which the music was heard conditioned audience response. 
Although American jazz musicians still visited Britain during the 1920s, many imitative British bands emerged. During this decade, jazz in Britain was heard in three primary ways: performed by dance bands at socially respectable venues such as hotels; performed by black music theatre companies; and performed by small groups of musicians in West End clubs (ibid.: 163). There was a growing sentiment-strongly encouraged by John Reith (later Lord Reith) of the BBC - that the British entertainment industry should be self-sufficient and should cease to rely heavily on imported musicians. (The overriding belief was that if jazz was included at all, it should be played, and therefore improved, by British musicians.) Some musicians and managers believed that the presence of American jazz bands had led to increased unemployment among British musicians, and in 1923 the British Musicians' Union (MU) issued a statement to that effect.

An extension of the Musicians' Union dissatisfaction was the legislation issued by the Ministry of Labour in 1935, which resulted in 'the Union [being] effectively able to veto the visits of most foreign musicians' (Musicians' Union n.d.); in practice this banned most visits by American jazz musicians. An exception to this ruling was made for servicemen such as Glenn Miller and his band, and American jazz musicians posing as cabaret or novelty acts frequently evaded the ruling. These circumventions of the ruling extend my argument that the way jazz was understood in the UK was conditioned by the way the music was presented, rather than by any intrinsic features or values associated with the music. If it was presented as cabaret, jazz music could be heard as cabaret; jazz presented in music halls would continue the music-hall tradition. While rank-and-file dance musicians expected to benefit from the ruling, jazz fans and aspiring jazz musicians in Britain lamented the loss of authentic jazz performances. ${ }^{5}$

\section{Rhythm Clubs, Concert Halls and Traditional Jazz: George Webb's Dixielanders}

Rhythm Clubs represent the main way in which jazz appreciation in Britain moved on from the identified 1920s patterns of jazz performance and reception. A side effect of the removal of American jazz bands in 1935 was a

5. The ban was reported in the Melody Maker thus: 'Whatever plans may now be hatching to bring any American bands to this country, for any class of work whatsoever, are likely to be completely frustrated as a result of an entirely new policy which the Melody Maker has every reason to believe has been adopted by the Ministry of Labour. The immediate effect will be to veto projected visits on the part of Duke Ellington's band and Fred Waring's Pennsylvanians' (Melody Maker 1935). 
surge in popularity of record circles for jazz appreciation, known as 'Rhythm Clubs'. From 1933 this British development built upon an earlier French trend for 'Hot Clubs', in which enthusiasts played and discussed records in a 'recital' context (Parsonage 2005: 72-4). The first British Rhythm Club (referred to as No. 1) was founded in July 1933 at 90-91 Regent Street in London (Godbolt 1986: 135). Rhythm Clubs became increasingly popular in Britain, and by May 1935 (as the Ministry of Labour ban took force and the British Federation of Rhythm Clubs was established), there were ninety Rhythm Clubs nationwide, and two publications dedicated exclusively to the phenomenon-Swing Music was launched in March 1935, and Hot News and Rhythm Record Review in April of that year (Parsonage 2005: 72). Over the ensuing years, New Orleans-style jazz became the most common genre heard at Rhythm Clubs. ${ }^{6}$

Contemporary and secondary accounts indicate that Rhythm Clubs had a different atmosphere from the live jazz performances of the 1920s. Trombonist Eddie Harvey recalled that Rhythm Clubs were places 'where people sat around listening to jazz records in a sort of sanctified silence' (Harvey 2010). They therefore helped to facilitate and develop a trend for close listening to recorded jazz performance. Jim Godbolt describes a varied, but predominantly middle-class, audience (1984: 138). The groups met in the back rooms of pubs and village halls-venues that were not purpose-built for music performance, but took on some of the aura and practices of concert halls. At what were often called 'record recitals', jazz enthusiasts sat in silence, focusing their attention on the gramophonereceiving jazz (albeit recorded jazz) in a fashion similar to music reception in classical concerts. ${ }^{7}$

Over the following years, a number of New Orleans-style ensembles emerged in Britain, as indigenous musicians strove to imitate the music they were hearing at Rhythm Clubs. It was but a small step for these venues to become live performance venues, with audiences primed for concert-style

6. The revivalist trend continued for several decades, and by the later 1950s was in concurrence with the 'trad' style, in which the same instrumentation and stylistic devices were used in popular music covers. Successful trad musicians included Chris Barber, Acker Bilk and Kenny Ball. George McKay provides lengthy descriptions and analyses of 1950s trad and revivalist jazz in Britain in his chapter on 'New Orleans Jazz, Protest (Aldermaston), and Carnival (Beaulieu)' (2005: 45-86).

7. See Christopher Small's Musicking (1998) for a description of the cultures and practices associated with concert attendance. Lawrence W. Levine explains the development of cultural hierarchies in nineteenth-century concert audiences in Highbrow/Lowbrow (1988). 
performances; by the mid-1930s live performance at Rhythm Clubs was a well-established practice. In 1943 one such live performance by George Webb's Dixielanders at the Red Barn public house in Barnehurst, south London (Bexleyheath and District Rhythm Club No. 130) was documented. This was one of the earliest performances of traditional New Orleans jazz in Britain and the first professional performance for Eddie Harvey, who was feted as 'Britain's first genuine "tailgate" trombonist', which lent a further air of authenticity to the occasion (Godbolt 1984: 197). ${ }^{8}$

Live performances of New Orleans-style jazz flourished in the Red Barn and similar venues over the following years. This indigenous second wave of jazz performance in Britain (after the imported first wave) therefore attained a concert-style reception that can in part be attributed to the medium through which the music was heard. Rhythm Clubs provided no visual stimulus such as that experienced in the variety-based performances of the ODJB, and thus they encouraged audiences to listen in silence, focusing on the source of the sound. This attention was transferred to the musicians when live performances occurred.

In the 1940s British revival of New Orleans-style jazz, bands such as George Webb's Dixielanders also performed their music in concert halls. Harvey explained that during his time with the Dixielanders, performances in clubs and concert halls were 'simultaneous right from the off' (2010). A few performances at the Memorial Hall in Farringdon, under the aegis of the Challenge Jazz Club, began the association of Dixieland jazz with communism (documented further by McKay 2005). Shortly afterwards, the Dixielanders were playing regularly at the King's Hall on Tottenham Court Road, in concerts organized by the Hot Club of London. The atmosphere and audience was transported from Rhythm Clubs to concert halls, an environment ensured by the organizing body. Harvey recalled:

\footnotetext{
We did a few concerts in prestigious concert halls in London, and a lot of people came. Because the word had spread about this band playing this music, and there were a lot of people that were interested. And it just seemed to be a fateful time, when people were interested in it. (2010)
}

The concert-style reception of Dixieland jazz in Britain can be attributed to the recital traditions of the Rhythm Clubs, rather than an adoption of existing classical-music parameters, and reflects a transference of reception

8. Harvey did not pursue this style of playing, choosing instead to focus on bebop from the late 1940s.

(c) Equinox Publishing Ltd 2014.

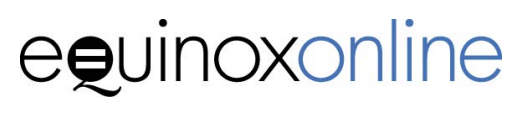


style between two types of venue, as similar audience members attended both types of event and behaved in a similar fashion. I asked Harvey if audiences responded differently to the Dixielanders' performances in Rhythm Clubs and the King's Hall. 'Not really', he said. 'They just shouted and that old stuff' (2010). His response implies that, although Rhythm Clubs had prompted an art-music-style appreciation of jazz, this was beginning to relax by the mid-1940s, even in a concert-hall environment.

\section{Multiple Styles in One Venue: The 100 Club}

As can be seen from the previous example, a 'jazz club' in Britain in the 1940s was not restricted to a particular venue, and referred instead to the group of people (or members) who shared the same enthusiasms for and ideologies about jazz. The fact that a jazz club was made up of members with shared attitudes rather than a fixed geographical space meant that clubs could be mobile and portable.

In 1942, the young swing drummer Victor Feldman's father hired the venue at Mack's Restaurant, 100 Oxford Street, on Sunday nights. His intention was to showcase his son and to provide a venue for swing dancing. In 1948, Feldman Senior adapted his policies, and introduced sessions of bebop on Sundays, changing the name from the Feldman Swing Club to the more generic London Jazz Club. In 1951, trumpeter Humphrey Lyttelton's agent Lyn Dutton took over 100 Oxford Street to enable Lyttelton to play New Orleans-style jazz for a dancing audience, and named the club night after his famous protégé. The following quotation, from one of Lyttelton's many memoirs, shows that in the British post-war era, the term 'jazz club' did not refer to a specific venue, but to a collection of musicians and fans, and a shared aesthetic:

In 1951 we parted company with the London Jazz Club and started our own jazz-for-dancing Club in the same Oxford Street premises on a different night of the week. (1954: 180)

In 1964, Roger Horton, who realized that the New Orleans revival in Britain was coming to an end, bought 100 Oxford Street. At this point, he changed the name to the 100 Club (a name still in use today), and introduced other styles of music. After forays into pop music in the 1960s, punk

9. Lyttelton was an eloquent and prolific jazz musician. His memoirs of his life and music, and his thoughts upon jazz and the music of the day, run to five volumes, listed in the Bibliography. 
in the 1970 s, ${ }^{10}$ and African jazz in the 1980s, in 1988 the 100 Club once again became home to jazz dance. Swing dance lessons accompanied by live bands have been a weekly feature of the club ever since.

When considering the mediation of jazz through venue, the most interesting aspect of this venue's long and varied musical history is not the diversity of styles hosted, but the fact that the 100 Club hosted different jazz communities featuring different styles on different nights of the week. This shows, therefore, that members of British jazz clubs were not tied to specific venues or locations, but supported their favourite musicians and styles wherever they might be playing. Venues carried differing cultural connotations, and audiences could expect specific reception styles within them, as the following example of Humphrey Lyttelton's negotiation between listening and dancing audiences indicates.

From the mid-1940s Lyttelton fronted a New Orleans-style group with Wally Fawkes and Eddie Harvey, continuing the art-music style presentation of the Rhythm Clubs. The arrival of Graeme Bell's Australian Band in London in 1948 prompted a change in reception format for New Orleansstyle jazz in Britain, for that band recommended that its audiences dance. Lyttelton applauded this idea, and he and his band started their own jazz club at the Café l'Europe in Leicester Square later that year, with the specific intention of enabling and encouraging audience members to dance. Harvey (who played in Lyttelton's band at the time) recalls:

It wasn't until Graeme Bell's band ... played their music [that] people started to dance to it. The continuation of that was that when it got well known later on, and [Lyttelton] started his own club ... people came there to dance. But prior [to that] people just sat and listened and were enthusiastic ... the idea of dancing to it would have been sort of sacrilegious. (2010)

Twenty years prior to this, British audiences had danced to the ODJB in the Dixie Club on Bond Street and the Hammersmith Palais. Dancing to jazz was thus still in cultural consciousness, and was embraced by a proportion of the existing jazz audience. However, the following advertisement from the 7 August 1954 issue of Melody Maker shows how Lyttelton and Dutton capitalized on British audiences' appetite for receiving jazz in different ways, assuming separate audiences listened or danced to jazz:

10. In 1976, the club hosted the first 'International Punk Festival', which featured bands such as the Sex Pistols, Siouxsie and the Banshees, The Clash, Buzzcocks, The Stranglers and The Damned.

(c) Equinox Publishing Ltd 2014.

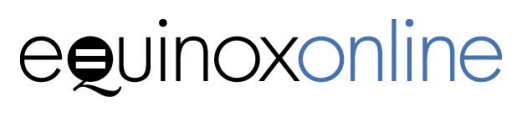




\title{
Humphrey Lyttelton Club
}

\author{
'Jazz for Dancing' \\ MACK'S, 100 Oxford Street, W.1 \\ Every Saturday, Monday and Wednesday \\ 'Jazz for listening' \\ Conway Hall, Holborn, W.C.1
}

The owners of the 100 Club were clearly aware that they could bring in different jazz audiences to the same venue by featuring swing, bebop and New Orleans-style jazz on different nights of the week. Lyttelton and Dutton provided a reversal of this phenomenon, showing how the same music could be performed to fulfil different functions for different audiences in different venues.

\section{Bebop Clubs on the Move in the UK: Ronnie Scott's Jazz Club}

In New York, musicians Charlie Parker, Dizzy Gillespie and Charlie Christian developed the bebop style from musical techniques developed in after-hours jazz sessions held in club rooms, basements and apartments (DeVeaux 2000: 293). By the 1950s, several bebop-only clubs had emerged, especially among those buildings that lined 52nd Street (such as the Onyx, the Famous Door, the Hickory House, Kelly's Stable, the Yacht Club, Jimmy Ryan's, the Three Deuces, and the Spotlight). The Royal Roost and Birdland (named after, and originally fronted by, Charlie 'Bird' Parker) opened on Broadway in the 1940s, and the Five Spot and the Halfnote elsewhere in New York in the 1950s. A small group of British musicians followed the developments of the bebop movement in New York in the early 1940s. These musicians included saxophonists Ronnie Scott, John Dankworth and Tubby Hayes. Scott recalls having difficulties obtaining 78 rpm records of bebop to listen to and learn from, because the already limited jazz market was geared towards New Orleans-style jazz (Scott 1979: 33). In 1947 Scott and Dankworth gained employment on the ocean liner Queen Mary, and travelled between England and New York several times in order to experience bebop live. ${ }^{11}$

11. The English bandleader Gerald Walcan Bright, who organized many such working 
On their return, the musicians were frustrated by the predominance of New Orleans-style jazz in Britain, and searched for a venue where they could express themselves artistically in the new style. In 1948 Scott, Dankworth and eight other British modern jazz musicians hired a rehearsal room on Great Windmill Street, which they ran co-operatively as Club Eleven, Britain's first bebop club. The musicians played there every night, experimenting in the new style. After a chance meeting with Dankworth, Harvey recalled becoming interested in bebop: 'Club Eleven ... became my university. I was one of the first bebop musicians to jump ship from a traditional jazz band to a bebop band' (2010). Consequently, Harvey became one of the founding members of an early British bebop group, the co-operative John Dankworth Seven. In 1950, Club Eleven moved from Great Windmill Street to 50, Carnaby Street. Fans loyally stayed with the musicians and style that they followed-when the club closed down soon after, this was due to a drugs raid by the police rather than lack of support from fans. ${ }^{12}$ The modern jazz scene in London's Soho had strong links with drugs, as documented in Scott's autobiography and Heining's study of British jazz in the 1960 s and 1970s. ${ }^{13}$

At the beginning of the 1950s two jazz venues with a focus on bebop existed in London: Studio 51 and the Feldman Club at 100 Oxford Street, which also hosted Lyttelton's 'jazz for dancing' London Jazz Club on other evenings. As bebop grew in popularity through the decade, several modern jazz clubs were founded in Soho. Prominent amongst these clubs were the Flamingo Club on Wardour Street (opened 1952), the Marquee Club on Oxford Street (opened 1958) and Ronnie Scott's Jazz Club on Gerrard Street (opened 1959). The London bebop clubs, and their American counterparts, were built for neither a dancing nor a concert audience. They still share a similar aesthetic: each club has a bar in its performance room, and many serve food. Audiences are seated at tables, on benches, or at the bar. Attention is focused on the stage, and near-silence is demanded.

A relaxation of the Ministry of Labour ruling in the 1950s meant that American jazz soloists could be 'exchanged' for British soloists. The reasoning was that local bands could still be hired to accompany visiting

trips for musicians at the time, arranged their travel. Musicians who travelled in this way were affectionately known as Geraldo's Navy (Scott 1979: 35).

12. Ronnie Scott recounts this episode with characteristic good humour in his autobiography (ibid.: 39-42).

13. In particular, Chapter 7, 'One Scotch, One Bourbon, One Beer', describes British jazz musicians' relationships with alcohol and drugs at this time (Heining 2012: 183-218).

(c) Equinox Publishing Ltd 2014.

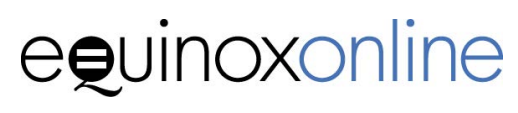


artists, and it would be a fruitful exchange of ideas rather than a reduction of opportunities for British musicians. This was something that Ronnie Scott took full advantage of when forming his own bebop club with fellow tenor saxophonist Pete King in October 1959. As Heining reports, 'Britain had needed the Americans in 1917 and again in 1941. Ronnie Scott's club needed them once more in 1961!' (2012: 99). Ronnie Scott's Jazz Club opened in an underground room on Gerrard Street in Soho. From its opening, the club featured up-and-coming British jazz musicians as a house band alongside the American greats and British soloists.

Photographs from the time (for example, Fordham 2009: 31) show rows of audience members seated in a cramped room, focusing their attention on the musicians. The British jazz critic John Fordham explains the attraction of a small jazz club for audiences:

\footnotetext{
Fans loved the proximity to the guests, the way they would be ushered through the parting crowd, up to the tiny stage to pick up one of Stan Tracey's quirky, sidelong piano introductions. Local musicians liked the club as a place to meet friends, maybe stay on for an after-hours jam session. (2009: 21)
}

The success of the club led to the need for larger premises, and in 1965 Scott and King moved the club to its current location at 47 Frith Street, just a few streets away. Photographs in Fordham's volume (2009: 31) show how Scott and King captured a similar atmosphere within the larger premises. The performance room is filled with tables and chairs for patrons, making dancing impossible even if the musical features of the bebop performed allowed it. The venue was therefore suited to the expected norms of audience behaviour in a bebop venue, which fell between the formality of nineteenth-century concert audiences and the behaviour of early jazz audiences. As is clear from the migration of Rhythm Club audiences to concert halls to support their favourite New Orleans-style bands, British jazz fans did not consider location an impediment to jazz clubs. When jazz clubs changed location for circumstantial reasons, fans would follow musicians between venues. This was particularly common within the central area of London's Soho.

\section{Jazz in Theatres: 1960s}

Jazz in Britain (and in America) underwent many changes of style in the 1960s and 1970s. The era marked an expansion and a departure from bebop, New Orleans-style and cool jazz (associated with the West Coast 
of America), which were the mainstays of 1950 s jazz. The development of many of these new styles can be attributed to club owners and patrons being open-minded to change and experimentation, showing that jazz in Britain continued to be mediated by venue.

In the late 1950s, alto saxophonist Joe Harriott led a group of musicians who experimented with free jazz. Ian Carr comments that Harriott's 'selfconscious experiment[ing] ... owed little or nothing to his American counterpart, Ornette Coleman' (2008: 46-7). A few years later, drummer John Stevens and the Spontaneous Music Ensemble (SME) also experimented with free jazz. Stevens was particularly important to the development of British jazz in the 1960s, because in 1966 he secured a venue for free-jazz musicians to play. Jean Pritchard, the owner of the Little Theatre Club (LTC) in the West End, allowed him to use the venue free of charge six nights a week. He opened the club as a jazz venue in January 1966:

The Little Theatre Club rapidly established itself as the platform and crucible for the ideas and experiments of the rising generation of musicians. Apart from providing a regular weekly playing spot for numerous little known musicians and groups, it also became the place where all kinds of musicians dropped in to listen or to sit-in when there was a loosely organized blowing session [jam]—which happened most nights. (ibid.: 54)

Carr explains the importance of the LTC to emerging free-jazz musicians. For example, saxophonist Evan Parker 'came to London in 1965 or 1966, and made straight for the Little Theatre Club' (ibid.: 87). But it is a comment by Stevens himself that makes clear the distinction that emerging free-jazz musicians felt there was between the LTC and established venues:

'When I came to London and started playing professionally as a jazz musician, I found that you had to play with people in a very cool way ... I thought the thing to do would be to play at Ronnie Scott's Club, because that's where l'd heard a lot of jazz. But the more I came into contact with the profession, the more it began to feel like the world of commercial art which l'd disliked so much ... So a significant thing was finding the Little Theatre Club. You got in there with people who were interested in the same group experiences and the music was allowed to develop day by day, literally.' (Stevens, quoted in Carr 2008: 52)

The connection between the Little Theatre Club and 1960s free jazz in Britain is interesting on two levels: not only were experimental practices from theatre easily transferred to the music created within the same venue, but the lack of a commercial framework for the LTC placed the free-jazz 
network outside London's established musical infrastructure, which by the mid-1960s included bebop clubs such as Ronnie Scott's Jazz Club. I have written elsewhere about the impact jazz musicians create outside the strictures of the academy (Williams 2013); the LTC is another occasion of jazz musicians creating music and styles outside institutionalized systems. Yet again, it is possible to see jazz venue influencing jazz practice.

After the move to Frith Street, Ronnie Scott's Jazz Club continued to provide an important service to new British jazz musicians. The lease on the 'Old Place' on Gerrard Street had eighteen months left after the move, and so Scott provided another venue for up-and-coming musicians. He recalled:

\begin{abstract}
Although we had shut up shop in Gerrard Street, Pete and I planned to reopen the basement as a place in which to present some of the excellent younger musicians who were coming on to the British jazz scene-and we finally took the step in September 1966 ... For the next two years - until the lease ran out and we were unable to afford to renew it at treble the previous figure-the Old Place presented some outstanding musicians, including Graham Collier, Mike Osborne, John Surman, Chris McGregor, Dudu Pakwana, Evan Parker, Tony Oxley and Mike Westbrook. It ran at a loss, but we were happy to subsidise it as long as we could afford to. (Scott 1979: 92)
\end{abstract}

The simultaneous existence of the Old Place and the LTC resulted in a shift in the 1960s London jazz scene. As the Old Place had a policy of paying musicians $£ 3$ a night, and the LTC did not pay its musicians, most groups gravitated towards the former venue. The only group to remain faithful to the LTC was the SME, which effectively created a stylistic split defined by venue. The more mainstream, bebop-influenced and commercially motivated groups played in Gerrard Street, while the spontaneous and free musicians remained at the LTC. The argument that free jazz occurred outside the commercially supported establishment can be furthered here; the Old Place was below the radar in that it was not the 'official' Ronnie Scott's Jazz Club, but even so the small fiscal subsidy available attracted musicians whose styles fell more into line with the commercial mainstream.

The importance and influence of venues on the development of jazz in Britain during the 1960s and 1970s can be illustrated further by the case of pianist and bandleader Mike Westbrook. Westbrook had attended Plymouth Art School after school and National Service, and moved to London with saxophonist John Surman in the early 1960s. Westbrook was prepared to work for his reputation: he arrived in London with an unknown eleven-piece band, but soon realized it was commercially unviable and 
formed a six-piece band with Surman (baritone), Mike Osborne (alto), Malcolm Griffiths (trombone), Harry Miller (bass) and Alan Jackson (drums). By playing at the Old Place during its eighteen-month existence, Westbrook's sextet began to become known. Westbrook's reputation as a composer was growing at this time, and he began to get commissions for largescale pieces outside London. In particular, he was interested in the visual aspect of music performance, and in drawing the audience in to create an event rather than a performance. He increased the instrumental forces he wrote for, and began to compose for big bands again. Between 1967 and 1971, he composed several large-scale works for jazz orchestra that drew on several influences, including Celebration (first performed in Liverpool, 1967), Marching Song (first performed in Plymouth, 1969), Release and Metropolis.

It is his 1970 s project Earthrise that showcases the link between British jazz and venue, for it was inspired by the use of the Mermaid Theatre on Puddle Dock in the City of London. The actor Bernard Miles and his wife Josephine Wilson had first opened a theatre in 1948 in an outdoor barn at their home in St John's Wood. They moved the venue to the Royal Exchange for their third season in 1953, and subsequently carried out the renovation of a derelict wharf at Blackfriars, funded by public subscription, in 1959. The Mermaid was the first new theatre to open in the City of London since 1700, and featured productions such as Lock up Your Daughters, a musical based on Henry Fielding's play Rape upon Rape, and Noël Coward's Cowardy Custard. Miles had the idea of using the venue for jazz and commissioned a new work from Westbrook.

Earthrise (1970) was the first of Westbrook's collaborations with John Fox, an advocate and practitioner of experimental theatre. Carr suggests that the work was 'probably his ultimate expression of the narrative/dramatic side of his conception' (2008: 35), for it combined his compositional style for an expanded big band with the dramatic use of theatre lights and film clips, still photographs and visual effects projected onto a screen behind the band. Westbrook has since described Earthrise as a programmatic 'piece of pure theatre' (ibid.: 36), which tells the story of a landing on the moon through music, choreography and lighting effects. The influence of venue on the development of jazz here is two-fold: first, Westbrook was able to utilize theatre techniques such as lighting and effects; and second, the extra-musical effects he incorporated had allusions to the staging of repertoire from the classical canon, such as Schoenberg's Die Glückliche Hand. 


\section{Conclusion}

Post-World War II London is a rich site for the examination of how venue mediates jazz performance and reception; this article has detailed four different modes of performance and reception. The listening audiences for New Orleans-style jazz established through the conventions of Rhythm Clubs transferred their concert-style reception to venues with classicalmusic connotations when British trad bands began performing in halls such as the King's Hall in the 1940s. The geographical flexibility of British jazz clubs and the non-specificity of performance venues in the period under consideration are shown by the diversity of performance style and audience response at venues such as the 100 Club. Here, audiences transcended the connotations of venues to respond to associations with musicians and styles.

The emergence of a British bebop following and musical scene in the 1940s led to the establishment of bebop-specific venues such as Club Eleven and Ronnie Scott's Jazz Club. Both these clubs expanded to larger premises shortly after opening, taking their fan base with them, and again proving the commitment of British jazz fans. London bebop venues and audience responses showed that place and reception style evolved in tandem.

Finally, theatres provided mediation for experimental jazz in two ways. The Little Theatre Club (and Ronnie Scott's 'Old Place') provided a venue for free jazz musicians to play and hone their style in the late 1960s, and venues such as the Mermaid Theatre were sites and inspiration for performances later that decade. Each of my four case studies has illustrated a different way in which British jazz was mediated by its performance venue and audience reception style between the years 1945 and 1970.

\section{Bibliography}

Anonymous. 'Musicians Union: A Social History, 1931-1940'. http://www.muhistory. com/?page id=196 (accessed 24 April 2014).

Berliner, Paul (1994) 'Vibes and Venues: Interacting with Different Audiences in Different Settings'. In Thinking in Jazz: The Infinite Art of Improvisation, 449-84. Chicago: The University of Chicago Press. http://dx.doi.org/10.7208/chicago/ 9780226044521.001.0001

Brunn, H. O. (1961) The Original Dixieland Jazz Band. London: Sidgwick and Jackson.

Burnim, Mellonee V., and Portia K. Maultsby, eds. (2006) African American Music: An Introduction. New York: Routledge. 
Carr, Ian (2008) Music Outside: Contemporary Jazz in Britain, 2nd edition. London: Northway Publications (first published 1973 by Latimer New Dimensions Ltd.).

Crease, Robert P. (2000) 'Jazz and Dance'. In The Oxford Companion to Jazz, ed. Bill Kirchner, 696-706. Oxford: Oxford University Press.

DeVeaux, Scott (2000) 'The Advent of Bebop'. In The Oxford Companion to Jazz, ed. Bill Kirchner, 292-304. Oxford: Oxford University Press.

Fordham, John (2009) Ronnie Scott's at Fifty. London: Palmgren Limited.

Godbolt, Jim (1986) A History of Jazz in Britain, 1919-50. London: Paladin Books (first published 1984).

Harvey, Eddie (2010) Interview with the author. Richmond, 2 March.

- (1988) Jazz in the Classroom. London: Boosey and Hawkes.

Heining, Duncan (2012) Trad Dads, Dirty Boppers and Free Fusioneers: British Jazz, 1960-1975. Sheffield: Equinox.

Levine, Lawrence W. (1988) Highbrow/Lowbrow: The Emergence of Cultural Hierarchy in America. Cambridge, MA: Harvard University Press.

Lyttelton, Humphrey (1954) I Play as I Please: The Memoirs of an Old Etonian Trumpeter. Letchworth: MacGibbon and Kee.

(1958) Second Chorus. Letchworth: MacGibbon and Kee.

(1975) Take It from the Top. London: Robson Books.

-(1978) The Best of Jazz: Basin Street to Harlem, Jazz Masters and Masterpieces 1917-1930. Harmondsworth: Penguin Books.

-(1984) Why No Beethoven? London: Robson Books.

McKay, George (2005) Circular Breathing: The Cultural Politics of Jazz in Britain. London: Duke University Press. http://dx.doi.org/10.1215/9780822387282

Melody Maker (1935) 'No American Bands Need Apply'. 30 March, p. 1.

Moore, Hilary (2007) Inside British Jazz: Crossing Borders of Race, Nation and Class. Aldershot: Ashgate.

Musicians' Union (n.d.) http://www.muhistory.com/?page id=196 ( accessed 24 April 2014).

Parsonage, Catherine (2005) The Emergence of Jazz in Britain: 1885-1935. Aldershot: Ashgate.

Pelote, Vincent (2000) 'Jazz Clubs'. In The Oxford Companion to Jazz, ed. Bill Kirchner, 722-33. Oxford: Oxford University Press.

Pickering, Michael (2008) Blackface Minstrelsy in Britain. Aldershot: Ashgate.

Schuller, Gunther (1968) Early Jazz: Its Roots and Musical Development. Oxford and New York: Oxford University Press.

Scott, Ronnie, with Mike Hennessey (1979) Some of My Best Friends Are Blues. London: W. H. Allen.

Small, Christopher (1998) Musicking: The Meanings of Performance and Listening. Middletown, CT: Wesleyan University Press.

Tackley, Catherine (2012) Benny Goodman's Famous 1938 Carnegie Hall Jazz Concert. Oxford: Oxford University Press.

Taylor, Jeff (2000) 'The Early Origins of Jazz'. In The Oxford Companion to Jazz, ed. Bill Kirchner, 39-52. Oxford: Oxford University Press.

Williams, John C. (2012) Interview with the author. Ratlinghope, Shropshire, 27 February 2010. 
Williams, Katherine. (2012) 'Valuing Jazz: Cross-cultural Comparisons of the Classical Influence in Jazz'. PhD thesis, University of Nottingham. http://etheses.nottingham.ac.uk/2622

(2013) 'The Relevance of Jazz History in British Jazz Practice and Pedagogy'. Journal of Music History Pedagogy 3/2 (Spring): 187-94.

\section{Websites}

http://www.birdlandjazz.com/history/ (accessed 23 May 2011).

http://www.evolvingstyles.co.uk/joomla10156/2008100576/STYLE-NATIVE/Clubland-History-THE-FLAMINGO-CLUB.html (accessed 18 March 2010).

http://www.hippodromecasino.com/info/history (accessed 26 July 2013).

http://www.reallyusefultheatres.co.uk/theatres/london-palladium/history/ (accessed 26 July 2013).

http://www.ronniescotts.co.uk.static.assets.ronnie scotts history.pdf (accessed 18 March 2010).

http://www.the100club.co.uk/history.asp (accessed 23 May 2011).

Voce, Steve. 'Graeme Bell Obituary'. Independent, 3 July 2012. http://www.independent.co.uk/news/obituaries/graeme-bell-musician-who-brought-back-dancing-to-british-jazz-7904282.html (accessed 4 December 2013). 
Reproduced with permission of the copyright owner. Further reproduction prohibited without permission. 